\title{
Hubungan Pola Asuh dan Status Gizi Balita Dengan Angka Kejadian Diare di Ruang Nusa Indah Bawah RSUD dr. Slamet Garut
}

\author{
Wahyudin $^{\text {I, Andhika Lungguh Perceka }}{ }^{2}$
}

\begin{abstract}
Abstrak
Faktor-faktor yang mempengaruhi diare adalah faktor Infeksi bakteri, virus, dan parasit, alabsorbsi, makanan, psikologis, kondisi lingkungan. Di negara yang sedang berkembang per tahun rata-rata anak mengalami diare 3-4 kali kejadian. Faktor penjamu (host) yaitu keadaan gizi, pola asuh ibu, perilaku hygiene. Asupan gizi tergantung pada proses sosial yang dilakukan ibu. Interaksi keluarga terutama ibu dan anak disebut pola pengasuhan. Penelitian ini bertujuan untuk mencari Hubungan Pola Asuh Dan Status Gizi Balita dengan Kejadian Diare di Ruang Nusa Indah Bawah RSUD dr. Slamet Garut. Metoda penelitian yang digunakan Deskriptif korelasional, jumlah sampel 62 responden, pengambilan data dilakukan dengan kuesioner. Hasil penelitian sebagian besar pola asuh ibu tidak efektif dan sebagian besar status gizi pasien balita kategori kurus di Ruang Nusa Indah Bawah RSUD dr. Slamet Garut. Kesimpulan antara pola asuh ibu terdapat hubungan dengan angka kejadian diare dan antara status gizi balita terdapat hubungan dengan angka kejadian diare di Ruang Nusa Indah Bawah RSUD dr. Slamet Garut. Disarankan agar memberikan pendidikan kesehatan kepada keluarga pasien mengenai pola asuh dan dan penanganan gizi pada anak untuk menghindari kejadian diare.
\end{abstract}

Kata kunci : Pola asuh, status gizi, diare

\section{Abstract}

The factors affecting diarrhea are factors of bacterial, viral, and parasitic infections, Alabsorbsi, food, psychological, environmental conditions. In the developing country per year the average child has diarrhea 3-4 times the incident. The host factor is a nutrient condition, mother's foster pattern, hygiene behaviour. Nutritional intake depends on the social process that mothers do. Family interactions especially mothers and children are called parenting patterns. PEnelitianaims to find the relationship of foster care and nutritional Status of toddlers with the incidence OF diarrhea in the room Nusa Indah under the Dr. Slamet Garut hospital. Researchs methods used descriptive correlational, sample count of 62 respondents, data retrieval carried out with questionnaires. The results of the study of most of the mother's foster pattern is ineffective and most of the nutritional status of the toddler patient skinny category in the space Nusa Indah under the Dr. Slamet Garut hospital. Conclusion between the mother's foster pattern there is a connection with the incidence of diarrhea and among the nutritional status of children there is a relationship with diarrhea incidence rate in Nusa Indah AREA under the hospital Dr. Slamet Garut hospital. It is recommended to provide health education to the patient family about the foster pattern and the nutrition treatment in children to avoid diarrhea.

Keywords: Foster pattern, nutritional Status, diarrhea

\section{PENDAHULUAN}

Di Indonesia jumlah penyakit dan angka kematian akibat diare masih tinggi. Berdasarakan laporan jumlah penyakit terbesar yang dilakukan oleh Subdit Diare, Kementrian Kesehatan pada tahun 2016 Insidensi Ratio (IR) penyakit diare 
423/1000 penduduk dan tahun 2017 menjadi 412/1000 penduduk (Kemenkes, 2017). Data di Jawa Barat tahun 2017 lebih dari 742.358 penderita, dan jumlah kasus diare pada anak lebih dari 269.765. Menurut Profil Kesehatan Kabupaten Garut tahun 2017 dilaporkan proporsi penderita rawat jalan diare di Puskesmas untuk balita 2,97\% yaitu lebih dari 24.203 penderita dari total 797.817 penderita penyakit lainnya (Dinkes Garut, 2017).

Pertumbuhan anak dipengaruhi oleh Gen keturunan dan lingkungan sebelum dan sesudah kelahiran yaitu gizi ibu waktu hamil. Gizi ibu yang tidak baik sebelum kehamilan maupun selama hamil, lebih beresiko melahirkan Bayi Berat Lahir Rendah (BBLR) atau lahir mati. Faktor sesudah kelahiran memiliki peran penting dalam pertumbuhan anak adalah faktor lingkungan biologis seperti gizi, imunisasi, penyakit dan faktor psikososial, seperti kualitas hubungan antara balita dan orang tua atau dikenal dengan pengasuhan (Soetjiningsih, 2009).

Pertumbuhan dan perkembangan juga tergantung pada proses sosial yang dilakukan keluarga terutama ibu terhadap anak yang dikenal dengan pengasuhan. Pola asuh anak merupakan interaksi orang tua dengan anaknya, berupa tindakan penyediaan waktu, perhatian dan dukungan orang tua guna memenuhi kebutuhan fisik, mental dan sosial (Santoso, 2009). Gambaran tersebut menunjukkan bahwa pola asuh dan kejadian penyakit infeksi khususnya diare, sangat penting peranannya dalam pertumbuhan dan perkembangan anak, khususnya untuk anak dengan hambatan pertumbuhan dalam rahim, karena akan berpengaruh langsung pada pemenuhan kebutuhan gizi balita.

Faktor lingkungan biologis yang berhubungan langsung dengan pertumbuhan anak adalah penyakit infeksi. Infeksi pada anak menyebabkan kehilangan persediaan zat gizi akibat respon metabolik, kehilangan melalui saluran cerna, dan menurunkan menurunkan nafsu makan, sehingga asupan gizi anak menurun.

Faktor lain yang mendukung tumbuh kembang anak yaitu pola asuh anak. Pola asuh anak merupakan hubungan timbal balik orang tua dengan anaknya, yang meliputi penyediaan waktu, perhatian dan dukungan orang tua guna memenuhi kebutuhan fisik, mental dan bermasyarakat. Pemenuhan kebutuhan fisik, kasih sayang, pola perilaku, bimbingan dan bantuan dalam mempelajari berbagai kecakapan anak diperoleh dari keluarga (Santoso, 2009). pada proses sosial yang dilakukan keluarga terutama ibu. Interaksi keluarga terutama ibu dan anak disebut pengasuhan. Pengasuhan anak mencakup pemeliharaan, pendidikan, pembinaan, perlindungan dan seluruh bentuk interaksi antara orang tua dan anak 
untuk pengembangan seluruh potensi anak (fisik, mental, akal dan rohani).

Gambaran tumbuh kembang bayi dan anak dengan berat lahir rendah dipengaruhi oleh pola asuh anak dan kejadian diare, khususnya bayi yang mengalami hambatan pertumbuhan akan mempengaruhi asupan gizi bayi. Diare merupakan penyakit yang dapat dicegah dan diobati namun diare yang berlangsung dalam durasi panjang dan terjadi dehidrasi dapat menimbulkan kematian. Penyakit diare pada anak lebih beresiko dibanding orang dewasa karena struktur tubuh balita lebih banyak mengandung air dibanding dewasa.

Kasus diare pada anak sebagain besar akan sembuh dengan sendirinya, tetapi diare yang berlangsung terus menerus menyebabkan keadaan dehidrasi. Peranan orang tua dalam pencegahan dan perawatan balita dengan diare sangatlah penting. Penanganan pada pasien diare memerlukan perawatan yang komprehensif dan rasional. Perawatan diare dilakukan untuk pencegahan dan penanggulangan dehidrasi dan gangguan gizi serta kesetimbangan asam basa, dan mengobati penyakit penyerta (Subijanto, 2009).

Jumlah 10 penyakit terbesar di RSUD dr. Slamet Garut pada tahun 2017 BHP 291 kasus, Diare 284 kasus, Tyfoid fever 258 kasus, Febris convulsi 247 dan Fabrris 241 kasus dan dari data yang diperoleh peneliti jumlah penderita diare satu tahun terakhir pada balita di RSUD dr. Slamet Garut mengalami peningkatan yaitu tahun 2016 sebanyak 263 kasus dan tahun 2017 naik menjadi sebanyak 284. peneliti memilih diare untuk diteliti. Dari observasi awal peneliti melakukan wawancara terhadap 10 orang tua balita, 6 orang mengatakan dalam 6 bulan terakhir balita mengalami diare sebanyak 2 kali, hal ini dikarenakan balita sering jajan di luar dan orang tua tidak mengawasi anak jajan di luar. Empat orang lainnya mengetahui mengenai cara pencegahan diare secara benar, namun terkadang tidak diketahui bila kebersihan makanan ketika sedang diluar, semua anak-anak yang mengalami diare berusia di bawah 6 tahun.

\section{METODE PENELITIAN}

Penelitian ini bertempat di Rumah Sakit Umum Daerah dr. Slamet Garut dengan pendekatan Deskriptif korelasional dengan populasi adalah seluruh balita yang menderita penyakit diare maupun tidak di Ruang Nusa Indah Bawah RSUD dr. Slamet Garut tahun 2018 sebanyak 784 kasus dan sampel sebanyak 62 responden dengan menggunakan teknik random sampling dengan teknik purposive sampling. Pengumpulan data penelitian ini menggunakan instrumen yaitu lembar kuesioner dengan pertanyaan terbuka.

Analisa data yang digunakan yaitu analisa Univariat. Data terjadi diare dan 
Tidak diare dibuat persentase. Dari persentase tersebut dapat diketahui berapa persen yang terjadi diare dan berapa persen tidak terjadi diare dan untuk mencari hubungan 2 variabel menggunakan analisa bivariat dengan uji Chi Kuadrat.

\section{HASIL DAN PEMBAHASAN}

\section{Hasil Penelitian}

a. Pola Asuh Ibu

Hasil penelitian pola asuh ibu pada pasien balita yang mengalami diare di Ruang Nusa Indah Bawah RSUD dr. Slamet Garut.

Tabel 1. Distribusi Frekuensi Pola Asuh Ibu Pada Pasien Balita di Ruang Nusa Indah Bawah RSUD dr Slamet Garut Pola Asuh $\quad$ Frekuensi (F) Prosentase

\begin{tabular}{lll}
\hline Efektif & 24 & 38,7 \\
Tidak Efektif & 38 & 61,3 \\
\hline \multicolumn{1}{c}{ Total } & $\mathbf{6 2}$ & $\mathbf{1 0 0}$ \\
\hline
\end{tabular}

Tabel 1. menunjukkan bahwa pola asuh ibu pada balita sebagian besar $(61,3 \%)$ tidak efektif..

b. Status Gizi Balita

Hasil penelitian status gizi pasien balita yang mengalami diare di Ruang Nusa Indah Bawah RSUD dr. Slamet Garut.

Tabel 2. Distribusi Frekuensi Status Gizi Pasien Balita Yang Mengalami Diare di Ruang Nusa Indah Bawah RSUD dr. Slamet Garut

\begin{tabular}{lcc}
\hline $\begin{array}{c}\text { Status } \\
\text { Gizi }\end{array}$ & $\begin{array}{c}\text { Frekuensi } \\
\text { (F) }\end{array}$ & $\begin{array}{c}\text { Prosentase } \\
(\mathbf{\%})\end{array}$ \\
\hline Normal & 21 & 33,9 \\
Kurus & 41 & 68,1 \\
Obesitas & - & - \\
\hline
\end{tabular}

Tabel 2 menunjukkan bahwa status gizi balita sebagian besar $(68,1 \%)$ kategori kurus.

c. Kejadian Diare

Hasil penelitian pada balita yang mengalami diare di Ruang Nusa Indah Bawah RSUD dr. Slamet Garut dapat dilihat pada tabel berikut ini :

Tabel 3. Distribusi Frekuensi Angka Kejadian Diare Pada Pasien Balita di Ruang Nusa Indah Bawah RSUD dr. Slamet Garut

\begin{tabular}{lcc}
\hline $\begin{array}{l}\text { Kejadian } \\
\text { Diare }\end{array}$ & $\begin{array}{c}\text { Frekuensi } \\
(\mathbf{F})\end{array}$ & $\begin{array}{c}\text { Prosentase } \\
(\mathbf{\%})\end{array}$ \\
\hline Tidak & 22 & 35,5 \\
Diare & & \\
Diare & 40 & 64,5 \\
\hline \multicolumn{1}{c}{ Total } & $\mathbf{6 2}$ & $\mathbf{1 0 0}$ \\
\hline
\end{tabular}

Tabel 3 menunjukkan bahwa sebagian besar balita (64,5\%) mengalami diare.

d. Hubungan Pola Asuh Dengan Kejadian Diare

Pengujian hipotesis hubungan pola asuh ibu dengan kejadian diare pada balita di Ruang Nusa Indah Bawah RSUD dr. Slamet Garut menggunakan Chi Kuadrat, dengan hasil dapat dijelaskan pada tabel berikut ini :

Tabel 4. Hubungan Pola Asuh dengan Kejadian Diare di Ruang Nusa Indah Bawah RSUD dr. Slamet Garut

\begin{tabular}{|c|c|c|c|c|c|c|c|}
\hline \multirow{2}{*}{$\begin{array}{l}\text { Pola } \\
\text { asuh }\end{array}$} & \multicolumn{6}{|c|}{ Kejadian Diare } & \multirow{2}{*}{$\begin{array}{c}p \\
\text { value }\end{array}$} \\
\hline & Tidak & $\%$ & $\mathrm{Ya}$ & $\%$ & Total & $\%$ & \\
\hline \multirow{2}{*}{$\begin{array}{c}\text { Efektif } \\
\text { Tidak } \\
\text { Efektif }\end{array}$} & 19 & 79,2 & 5 & 20,8 & 24 & 100 & \multirow[t]{2}{*}{0} \\
\hline & 3 & 7,9 & 35 & 92,1 & 38 & 100 & \\
\hline & $\mathrm{rdz}$ & ka & & bel & 4 & $\mathrm{di}$ & atas \\
\hline
\end{tabular}


yang tidak efektif, hampir seluruh balita (92,1\%) mengalami diare. Hasil uji hipotesis dengan Chi Kuadrat menyatakan bahwa terdapat hubungan yang bermakna antara pola asuh dengan kejadian diare dengan $p$ value sebesar $0,0001(<0,05)$.

\section{e. Hubungan Status Gizi Dengan Kejadian}

Diare

Pengujian hipotesis hubungan status gizi dengan kejadian diare pada balita di Ruang Nusa Indah Bawah RSUD dr. Slamet Garut menggunakan Chi Kuadrat, dengan hasil dapat dijelaskan pada tabel 5 berikut ini :

Tabel 5. Hubungan Status Gizi dengan Kejadian Diare di Ruang Nusa Indah Bawah RSUD dr. Slamet Garut

\begin{tabular}{lccccccc}
\hline Status & \multicolumn{6}{c}{ Kejadian Diare } & $p$ \\
\cline { 2 - 6 } Gizi & Tidak & $\%$ & Ya & $\%$ & Total & $\%$ & value \\
\hline Normal & 18 & 85,7 & 3 & 14,3 & 21 & 100 & 0,0001 \\
Kurus & 4 & 9,8 & 37 & 90,2 & 41 & 100 & \\
\hline
\end{tabular}

Berdasarkan tabel 5 di atas menunjukkan bahwa proporsi status gizi dengan kategori kurus, hampir seluruh balita $(90,2 \%)$ mengalami diare. Hasil uji hipotesis dengan Chi Kuadrat menyatakan bahwa terdapat hubungan yang bermakna antara status gizi dengan kejadian diare dengan $p$ value sebesar $0,0001(<0,05)$.

\section{Pembahasan}

a. Pola Asuh Ibu

Bila dilihat dari pola asuh ibu pada balita sebagian besar $(61,3 \%)$ tidak efektif.
Pola asuh merupakan hubungan timbal balik antara orang tua dan anaknya yaitu bagaimana sikap atau perilaku orang tua saat berinteraksi berupa pendidikan, perhatian, dan kasih sayang dengan tujuan mampu memberikan dorongan kepada anak untuk berprilaku yang baik, dan memiliki pengetahuan serta nilai-nilai yang dianggap paling tepat oleh orang tua, agar anak mandiri, tumbuh dan berkembang secara sehat dan optimal (Aisyah, 2012). Bila pola asuh tidak baik, maka perkembangan anak akan tidak terkontrol. Asupan gizi dan kesehatan menjadi tidak diperhatikan, dampaknya adalah gizi kurang dan mudah terserang penyakit diantaranya diare. Sebagaimana hasil penelitian Isnaini (2016) megenai Hubungan Pola Asuh, Pola Makan Dan Penyakit Infeksi Dengan Kejadian Gizi Buruk Pada Balita di Kabupaten Magetan, dihasilkan ada hubungan antara pola asuh dengan pola makan, dengan kejadian penyakit infeksi dan gizi buruk.

Pola asuh merupakan sikap dan perilaku orang tua dalam berinteraksi dengan anak. Sikap dan perilaku orang tua tersebut dapat dilihat dari cara orang tua menanamkan disiplin pada anak, mempengaruhi emosi dan cara orang tua dalam mengontrol anak (Nafratilawati. 2014).

Pola asuh yang benar dapat ditempuh dengan memberikan perhatian yang penuh serta kasih sayang pada anak, 
memberinya waktu yang cukup untuk menikmati kebersamaan dengan seluruh anggota keluarga. Dalam masa pengasuhan, lingkungan pertama yang berhubungan dengan anak adalah orang tuanya.

\section{b. Status Gizi}

Ukuran tentang keadaan tubuh berdasarkan asupan makanan yang disantap dan zat gizi yang dibutuhkan oleh tubuh manusia dapat diartikan sebagai status gizi. Status gizi dibagi menjadi tiga kategori, yaitu status gizi kurang, gizi normal, dan gizi lebih (Almatsier, 2010). Hasil penelitian ini sesuai tabel 2 diketahui bahwa status gizi balita sebagian besar $(68,1 \%)$ kategori kurus. Penyebab kurang gizi, dibagi menjadi 2 bagian besar, yaitu penyebab langsung dan penyebab tak langsung. Penyebab langsung mencakup kurangnya asupan gizi dari makanan dan penyakit infeksi. Kurang gizi juga dapat disebabkan secara tidak langsung seperti ketersediaan ada atau tidaknya makanan, tesedianya pusat perawatan dan pelayanan kesehatan untuk anak ketika sakit, pengetahuan dan pendidikan orang tua, kondisi ekonomi dan sosial sesesorang dan sebagainya.

Penyebab kekurangan gizi di Indonesia salah satunya yaitu standar kehidupan masyaraknya masih di bawah standar. Keadaan demikian sangat berpengaruh pada kecukupan gizi dalam suatu keluarga. Keluarga yang masuk dalam kategori miskin, rentan terkena masalah kekurangan gizi. Hal ini dikarenakan karena rendahnya kemampuan untuk memenuhi gizi yang baik. Ada beberapa sindroma kemiskinan yang dapat mempengaruhi status gizi. Pertama pendapatan yang tidak menjangkau untuk segala kebutuhan pangan, sandang dan papan. Kedua, kualitas dalam mengonsumsi makanan cenderung rendah, tanpa memperhatikan nilai gizi di dalamnya. Ketiga adalah sanitasi dan akses kesehatan yang buruk.

Faktor ekonomi keluarga yaitu pendapatan keluarga menjadi penyebab gizi tidak terpenuhi, hal ini terjadi karena pendapatan keluarga minimal yang didapat tidak mampu memenuhi kebutuhan dasar manusia dalam kebutuhan pokok yaitu pangan tidak terpenuhi maka kecukupan nutrisi dan gizi tidak maksimal sehingga menyebabkan masalah kurang gizi atau ketidakseimbangan nutrisi tubuh.

Status gizi dan kesehatan merupakan salah satu faktor yang sangat menentukan kualitas perkembangan anak. Status Gizi yang baik dipengaruhi oleh jumlah asupan zat gizi yang dikonsumsi. Oleh karena itu anak-anak yang kekurangan gizi akan mengalami gangguan pertumbuhan fisik, mental dan intelektual. Pemenuhan gizi pada balita sangat dibutuhkan untuk perkembangan anak. Status gizi kurang baik, maka anak akan rentan terserang penyakit. Perlu pengendalian gizi dengan 
baik yaitu dengan menerapkan pola asuh yang efektif, sehingga pola makan menjadi terkontrol dan status gizi anak menjadi baik.

\section{c. Kejadian Diare}

Hasil penelitian sesuai dengan tabel 5 sebagian besar balita (64,5\%) mengalami diare. Diare adalah buang air besar dengan frekuensi lebih dari biasanya tiga kali atau lebih dalam sehari berupa cairan (Kemenkes RI 2011). Faktor lingkungan biologis yang berhubungan langsung dengan pertumbuhan bayi adalah penyakit infeksi. Penyakit infeksi yang berkaitan dengan terjadinya guncangan pertumbuhan dan tingginya angka kematian bayi adalah infeksi saluran pernapasan akut (ISPA) dan diare (Wahyuningsih, Sri. Dkk. (2016).

Dampak diare terhadap keadaan gizi dan pertumbuhan lebih dahsyat daripada infeksi lain, karena selama diare terjadi gangguan masukan makanan, gangguan absorspi dan gangguan metabolisme secara bersamaan. Diare dapat dikatakan sebagai masalah pediatrik sosial karena diare merupakan salah satu penyakit utama yang terdapat di negara berkembang, dimana adanya faktor yang mempengaruhi terjadinya diare pada balita itu sendiri yaitu diantaranya faktor penyebab (agent), penjamu (host), dan faktor lingkungan (environment).
Penyebab tingginya kejadian diare kemungkinan besar disebabkan oleh adanya berbagai macam faktor resiko penyakit diare antara lain kondisi sanitasi lingkungan yang kurang baik, hygiene perorangan yang kurang baik, sanitasi makanan yang kurang baik, masalah nutrisi dan imunitas tubuh. Pengendalian kebersihan makanan dan lingkungan sangat dibutuhkan. Anak rentan dengan kejadian diare bila pengasuhan pada anak kurang diperhatikan. Pola asuh yang baik akan menjadikan anak terhindar dari diare. Penerapan hidup bersih sangat dianjurkan, khususnya perilaku hygiene seperti mencuci tangan dengan menggunakan sabun yang benar dan tepat sebagai cara yang efektif untuk mencegah penyebaran berbagai penyakit menular seperti penyakit diare (Fenioktaviani. 2010).

Berat dan lamanya diare sangat dipengaruhi oleh status gizi penderita dan diare yang diderita oleh anak dengan status gizi kurang lebih berat dibandingkan dengan anak yang status gizinya baik karena anak dengan status gizi kurang lebih banyak keluaran cairan elektrolit dalam tubuh balita dan tinja lebih banyak sehingga anak akan menderita dehidrasi berat bahkan sampai dapat menyebabkan kematian karena diare, hal ini disebabkan karena dehidrasi dan malnutrisi.

Menurut pandangan peneliti kejadian diare dapat terjadi pada semua kalangan umur, termasuk balita dapat terjadi karena 
perilaku ibu yang kurang membiasakan hidup bersih dan sehat, kurang memperhatikan pola asuh yang baik. Pada balita diare tertular melalui makanan dan minuman yang terkontaminasi virus dan bakteri, kebiasaan anak yang suka memasukkan mainan atau jari tangan yang telah terkontaminasi bakteri ke dalam mulut. Klasifikasi diare beradasarkan lama waktu, terdiri dari diare akut, diare persisisten dan diare kronis; Pada klarifikasi diare dapat dikelompokkan menjadi diare cair akut, disentri, dan diare yang menetap atau persisten.

d. Hubungan Pola Asuh Dengan Kejadian Diare

Pengasuhan anak adalah sebuah interaksi yang terjadi antara pengasuh (orangtua, orang dewasa) dengan anak-anak yang diasuh. Pengasuhan merupakan usaha yang diarahkan untuk mengubah tingkah laku sesuai dengan keinginan pengasuh. Pola asuh orang tua merupakan pola perilaku yang paling menonjol atau paling dominan dalam menangani anaknya sehari-hari. Pola asuh orang tua tersebut seperti dalam mendisiplinkan anak, dalam menanamkan nilai-nilai hidup, dan mengajarkan keterampilan hidup, dan mengelola emosi. Dampak kurang baik dalam pola asuh terhadap anak, anak menjadi tidak terkontrol baik dalam makanan dan kesehatannya. Kesehatan yang tidak terkontrol mudah terkena penyakit, diantaranya adalah diare. penyakit diare pada anak dapat terjadi karena pola makan dan lingkungan yang kurang bersih (Ngastiyah. 2013).

Berdasarkan hasil pengolahan data sesuai tabel 4 menunjukkan bahwa proporsi pola asuh yang tidak efektif, hampir seluruh balita $(92,1 \%)$ mengalami diare. Hasil ini memperlihatkan bahwa salah satu penyebab terjadinya penyakit adalah kurang baiknya kita dalam perilaku kehidupan sehari hari, seperti kurang bersih dalam pengontrolan makanan dan lingkungan di dalam dan di luar rumah. Diperkuat berdasarkan hasil uji hipotesis dengan Chi Kuadrat menyatakan bahwa terdapat hubungan yang bermakna antara pola asuh dengan kejadian diare dengan $\mathrm{p}$ value sebesar 0,0001 $(<0,05)$. Makna dari penelitian ini adalah pola asuh yang kurang baik, maka anak rentan terkena penyakit diare.

Pola asuh yang tidak efektif mengakibatkan pengontrolan terhadap anak menjadi kurang baik. Perilaku anak sehari-hari kurang diperhatikan, demikian pula dalam hal pola makan juga kurang diperhatikan. Kondisi ini menyebabkan kondisi kesehatan anak menjadi lemah yang memudahkan penyakit pada anak tersebut. Pengontrolan terhadap makanan yang kurang sehat adalah satu penyebab terjadinya diare (Widjaja. 2003).

Proses terjadinya diare ini dapat diawali adanya parasit yang masuk dalam 
saluran pencernaan dan berkembang biak dalam usus sehingga merusak sel mukosa usus dan permukaan usus menjadi menurun dan kapasitas usus berubah sehingga mengganggu fungsi usus dalam menyerap cairan dan elektrolit dan sistem transpor aktif yang disebabkan oleh bakteri dalam usus sehingga sel mukosa mengalami iritasi yang kemudian sekresi cairan dan elektrolit meningkat (Kemenkes, 2014).

Orang tua harus memberikan pola asuh yang baik, sehingga anak terkontrol baik fisik maupun mental. Semua orangtua harus memberikan hak anak untuk tumbuh dan berkembang serta memperoleh yang terbaik sesuai dengan kemampuan tubuhnya.

Bimbingan dan penyuluhan petugas kesehatan sangat dibutuhkan untuk mlebih meningkatkan peran ibu terhadap pengasuhan anak. Pengasuhan anak yang baik, anak akan tumbuh sehat baik fisik maupun mental. Terjaga dan terlindungi oleh peran orang tua dalam bentuk pengasuhan yang efektif, sehingga anak tumbuh dan berkembang sesuai pendampingan orang tua, serta terjaga kesehatannya dan tidak mudah terkena oleh suatu penyakit.

e. Hubungan Status Gizi dengan Kejadian Diare

Dalam hal pola asuh terhadap anak, sering dikatakan bahwa ibu adalah jantung dari keluarga, jantung dalam tubuh merupakan alat yang sangat penting bagi kehidupan seseorang. Apabila jantung berhenti berdenyut maka orang itu tidak bisa melangsungkan hidupnya. Dari perumpaan ini bisa disimpulkan bahwa kedudukan seorang ibu sebagai tokoh sentral dan sangat penting untuk melaksanakan kehidupan. Pentingnya seorang ibu terutama terlihat sejak kelahiran anaknya (Gunarsa, 2013). Salah satu bentuk dari pola asuh yang baik adalah memberikan asupan makanan pada anak sesuai dengan standar kebutuhan gizi, sehingga anak dapat tumbuh kembang dengan baik.

Berdasarkan hasil penelitian dan pengolahan data sesuai tabel 5 di atas menunjukkan bahwa proporsi status gizi dengan kategori kurus, hampir seluruh balita (90,2\%) mengalami diare. Menurut penelitian Hafrida (2014), terdapat kecendrungan pola asuh dengan status gizi. Status gizi anak yang di asuh orang tua memiliki proporsi gizi yang lebih baik dan akhirnya akan mempengaruhi keadaan gizi anak.

Diperkuat juga dengan hasil uji hipotesis pada penelitian ini dengan Chi Kuadrat menyatakan bahwa terdapat hubungan yang bermakna antara status gizi dengan kejadian diare dengan $\mathrm{p}$ value sebesar 0,0001 $(<0,05)$.

Gizi mempunyai pengaruh yang sangat berperan bagi pertumbuhan dan perkembangan mental maupun fisik anak. 
Gizi kurang anak menjadi mudah terkena penyakit dan pertumbuhan terganggu. Anak umur 2-5 tahun merupakan konsumen aktif yang biasa terpapar dari makanan diluar rumah (Palupi, Hadi, dan Soenarto2009). Pada umur tersebut, anakanak lebih suka makan jajanan mengikuti jejak teman-temannya, padahal pengolahan dan penyajian makanan tersebut kemungkinan kurang higienis yang berakibat pada kontaminasi makanan oleh kuman yang dapat menyebabkan seorang anak menderita diare.

Dalam keadaan normal, dimana keadaaan kesehatan baik, keseimbangan antara konsumsi dan kebutuhan zat zat gizi terjamin, maka berat badan berkembang mengikuti pertambahan umur. Sebaliknya dalam keadaan yang abnormal terdapat dua kemungkinan perkembangan berat badan, yaitu dapat bekembang cepat atau normal. Berkembang cepat atau lambat dari keadaan normal. Berdasarkan tinggi karakteristik berat badan ini, maka indeks berat badan menurut umur digunakan salah satu cara pengukuran status gizi (supariasa 2012).

Status gizi balita merupakan hal penting yang harus diketahui dan diperhatikan oleh setiap orang tua. Pada masa tumbuh kembang balita berada dalam kondisi rentan akan penyakit dikarenakan kurangnya gizi pada balita, sehingga dibutuhkan perhatian lebih oleh para orang tua.
Pandangan peneliti bahwa status gizi merupakan faktor resiko yang paling berpengaruh dalam kejadian diare pada balita, keadaan gizi buruk akan lebih cepat terserang diare. Oleh karena itu disarankan untuk petugas kesehatan untuk memberikan penyuluhan tentang cara penanganan gizi balita dengan kejadian diare. Penyuluhan kesehatan yang diberikan dapat berupa faktor-faktor yang mengakibatkan diare, cara pencegahan diare perilaku untuk hidup bersih dan sehat serta memberikan penyuluhan gizi yang baik dan seimbang serta penerapan pola asuh yang baik dan efektif.

\section{KESIMPULAN DAN SARAN}

\section{Kesimpulan}

Dari hasil pengolahan dan pembahasan mengenai hubungan pola asuh dan status gizi balita dengan angka kejadian diare di Ruang Nusa Indah Bawah RSUD dr. Slamet Garut Tahun 2018, disimpulkan bahwa Sebagian besar pola asuh ibu pada pasien balita yang mengalami diare di Ruang Nusa Indah Bawah RSUD dr. Slamet Garut tidak efektif, status gizi pasien balita yang mengalami diare dalam kategore kurus, terdapat hubungan pola asuh ibu dengan angka kejadian diare di Ruang Nusa Indah Bawah RSUD dr. Slamet Garut, terdapat hubungan status gizi balita dengan angka kejadian diare di Ruang Nusa Indah Bawah RSUD dr. Slamet Garut, Sebagian besar 
balita mengalami diare di Ruang Nusa Indah Bawah RSUD dr. Slamet Garut

Saran

Bagi Institusi Kesehatan RSUD dr.Slamet hendaknya memberikan Pendidikan kesehatan kepada keluarga pasien mengenai pola asuh dan penanganan gizi pada anak untuk menghindari kejadian diare.

Bagi Perawat diharapkan tenaga keperawatan dapat memberikan informasi dan edukasi mengenai pentingnya penerapan pola asuh yang tepat yang dapat menyelaraskan polaasuh dan pemberian gizi padabalita yang seimbang untuk menghindari kejadian diare

1, 2 STIKes Karsa Husada Garut

\section{DAFTAR PUSTAKA}

Almatsier, S. (2009). Prinsip Dasar Ilmu Gizi. Jakarta : PT Gramedia Pustaka Utama.

Dinkes, Garut. (2017) Profil Kesehatan Garut Tahun 2017, Garut : Dinas Kesehatan Garut

Gunarsa, Dr Singgih D. (2013). Psikologi Perkembangan. PT BPK Gunung Mulia, Jakarta

Kemenkes RI. (2011). In Buku Saku Lintas Diare (Lima Langkah Tuntaskan Diare). Jakarta: Kemenkes RI.
Kemenkes. (2017). Data Dan Informasi Profil Kesehatan Indonesia. Kementrian Kesehatan Republik Indonesia

Ngastiyah. (2013). Perawatan Anak Sakit(2 ed.). Jakarta: Buku Kedokteran.

Palupi, A., Hadi., Soenarto, S.S. (2009). Status Gizi dan Hubungannya dengan Kejadian Diare Pada Anak Diare Akut di Ruang Rawat Inap RSUP Dr. Sardjito Yogyakarta. Jurnal Gizi Klinik Indonesia Vol. 6. No. 1 bulan Juli. Yogyakarta.

Santoso, S, \& Ranti, A.L. (2009). Kesehatan Gizi. Jakarta: Rhineka Cipta.

Soetjiningsih. (2009). Tumbuh Kembang Anak. Jakarta : EGC.

Supariasa, (2012). Penilaian Status Gizi. Jakarta: EGC

Wahyuningsih, Sri. Dkk. (2016). Infeksi Saluran Pernafasan Akut (ISPA) pada Balita di Wilayah Pesisir Desa Kore Kecamatan Sanggar Kabupaten Bima. Jurnal Kesehatan lingkungan. UIN Alauudin Makasar. Vol 3 No 2. Pp: 95-105.

Widjaja, M.C., (2003), Mengatasi diare dan keracunan pada balita, Kawan Pustaka, Jakarta. 